\title{
Fish colonization of artificial reefs in a large Neotropical reservoir: material type and successional changes
}

\author{
Luciano N. Santos,,${ }^{1,4}$ Emili García-Berthou, ${ }^{2}$ Angelo A. Agostinho, ${ }^{3}$ and João D. Latini ${ }^{3}$ \\ ${ }^{1}$ Department of Ecology and Marine Resources, Federal University of Rio de Janeiro State, Rio de Janeiro, Brazil \\ ${ }^{2}$ Institute of Aquatic Ecology, University of Girona, E-17071, Girona, Catalonia, Spain \\ ${ }^{3}$ Department of Biology/NUPELIA, Maringá State University, Maringá, Paraná, Brazil
}

\begin{abstract}
Artificial reefs have barely been used in Neotropical reservoirs (about five studies in three reservoirs), despite their potential as a fishery management tool to create new habitats and also to understand fish ecology. We experimentally assessed how reef material (ceramic, concrete, and PVC) and time modulated fish colonization of artificial reefs deployed in Itaipu Reservoir, a large reservoir of the mainstem Paraná River, Brazil. Fish richness, abundance, and biomass were significantly greater in the reef treatments than at control sites. Among the experimental reefs, ceramic followed by the concrete treatments were the materials most effectively colonized, harboring the majority of the 13 fish species recorded. Although dependent on material type, many of the regularities of ecological successions were also observed in the artificial reefs, including decelerating increases in species richness, abundance, mean individual size, and species loss rates with time and decelerating decreases of species gain and turnover rates. Species composition also varied with material type and time, together with suites of life history traits: more equilibrium species (i.e., fishes of intermediate size that often exhibit parental care and produce fewer but larger offspring) of the Winemiller-Rose model of fish life histories prevailed in later successional stages. Overall, our study suggests that experimental reefs are a promising tool to understand ecological succession of fish assemblages, particularly in tropical ecosystems given their high species richness and low seasonality.
\end{abstract}

Key words: artificial habitats; ecological succession; experimental reefs; fishery management; freshwater reef fishes; impoundment; Paraná River, Brazil; tropical ecosystems.

\section{INTRODUCTION}

Fishery managers have long recognized the potential of artificial reefs to attract and yield fish (Wills et al. 2004). Since the 1930s, the use of artificial reefs in reservoirs has become widespread, especially in North America, where numerous studies have been undertaken to elucidate their role on the attraction, concentration, and enhancement of fishery resources (Bolding et al. 2004). The understanding of whether artificial reefs are effective in attracting fishery resources or restoring fish habitats in reservoirs is, however, complicated by the stochastic factors inherent to large-scale field experiments. For instance, depth, temperature, and other environmental variables of the sites where the reefs are deployed may determine their effectiveness (Walters et al. 1991). Material type, size, age, and complexity of the reefs are other crucial factors that affect fish colonization (Wills et al. 2004). Although habitat management represents an interesting opportunity to mitigate the impacts of dam construction and operation routines (Agostinho et al. 2005), the use of artificial reefs has

Manuscript received 15 July 2009; revised 22 January 2010; accepted 1 March 2010. Corresponding Editor: K. Stokesbury.

${ }^{4}$ E-mail: luciano.santos@unirio.br received little attention in South America. Few studies, all performed in Brazil, have investigated the use of artificial reefs by fish in Neotropical reservoirs (Freitas et al. 2002, 2005, Santos et al. 2008), and the majority have only described the general use of artificial structures by fish assemblages. Neotropical reservoirs are quite different from those in temperate zones, mainly because of greater constancy of environmental variables and more diverse fish assemblages (Lowe-McConnell 1987).

In addition to the applied interest of artificial reefs in Neotropical environments, they might also help to understand the mechanisms of ecological succession in aquatic ecosystems. Succession refers to the changes observed in an ecological community following a perturbation that opens up a relatively large space; these changes often involve a sequence of species and increases in biomass and diversity (Connell and Slatyer 1977). Succession has been mostly studied in terrestrial ecosystems (Anderson 2007) and experimental reefs have been widely used in marine ecology (e.g., Molles 1978, Talbot et al. 1978) but barely in freshwater environments, probably because of their low fish richness at temperate latitudes. Verifying succession theory is also central to disentangle specific issues within artificial reef research, such as the attraction vs. 


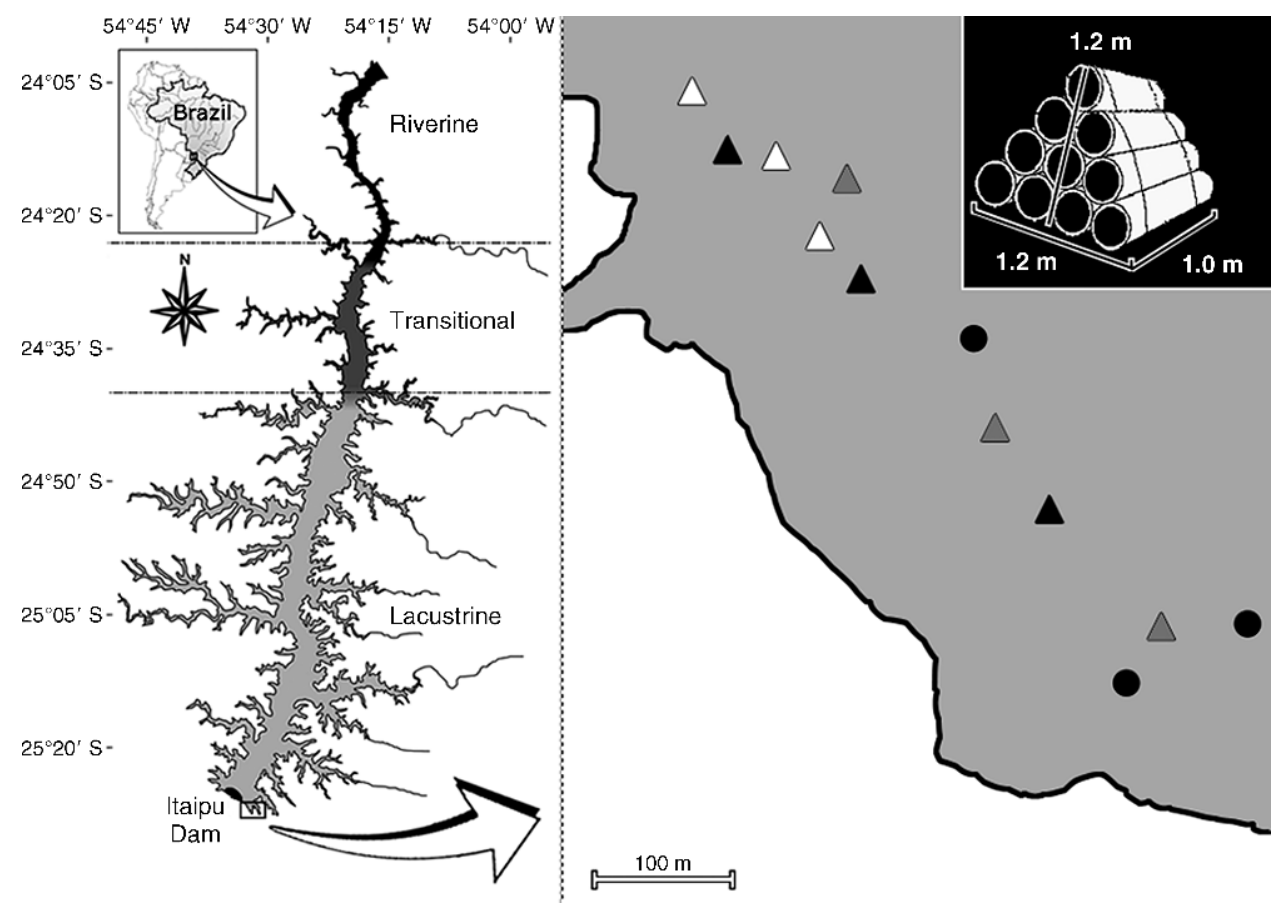

FIG. 1. Geographic location of Itaipu Reservoir (Brazil), where the experimental reefs were deployed. The final pyramidal arrangement of the reef replicates and the sites where controls (solid circle), ceramic (solid triangle), concrete (gray triangle), and PVC (open triangle) treatments were located are also shown.

production debate, which has lasted for decades (Lindberg 1997, Brickhill et al. 2005). Despite the many efforts to appraise whether artificial marine reefs increase fish abundance by merely attracting fishes from surrounding habits or actually providing new individuals by production (Brickhill et al. 2005), the attraction vs. production issue has received little attention in fresh waters (but see Bassett 1994, Santos et al. 2008). In this paper, we analyzed the colonization patterns of fish assemblages in artificial reefs deployed at Itaipu Reservoir, a large impoundment of the main Paraná River channel. Our objective was to experimentally address how reef material and time mediate fish colonization of artificial reefs, under a recent conceptual framework of ecological succession (Anderson 2007), which has the power to appraise the importance of competition, dispersal, or abiotic limitations as successional mechanisms, through temporal analyses of species gain, loss, and turnover. We analyzed how reef material and time affected general community descriptors (richness, abundance, and size structure), species composition, and functional attributes (life history traits) of fish assemblages. Following Anderson (2007), we evaluated species turnover rate as the average of gain and loss of species in order to understand the successional changes in fish richness. We predicted that most attributes such as richness, abundance, or fish size would increase in a decelerating manner with time but would depend on reef material. We also expected that, because of the features of our study system (high species richness, relatively short time scale of our study, and no resource depletion), we should observe a nonlinear relationship of turnover rates with time (Anderson 2007).

\section{Methods}

\section{Study area}

Itaipu Reservoir $\left(24^{\circ} 05^{\prime}-25^{\circ} 33^{\prime} \mathrm{S}\right.$; $\left.54^{\circ} 00^{\prime}-54^{\circ} 37^{\prime} \mathrm{W}\right)$ is a $1350-\mathrm{km}^{2}$ impoundment of the Paraná River located on the Brazil-Paraguay border (Fig. 1), which was filled in 1982 for hydroelectric purposes. This reservoir is 151 $\mathrm{km}$ long, covers a drainage basin area of $\sim 820000 \mathrm{~km}^{2}$, and has a mean depth of $22 \mathrm{~m}$. With a mean discharge of $8200 \mathrm{~m}^{3} / \mathrm{s}$, the reservoir has a water residence time of $\sim 40$ days and becomes thermally stratified from spring to summer (Agostinho et al. 2007). Although the reservoir is mesotrophic according to its concentrations of phosphorus $\left(22 \mathrm{mg} / \mathrm{m}^{3}\right)$ and chlorophyll $\left(3.6 \mathrm{mg} / \mathrm{m}^{3}\right)$ (Andrade et al. 1988), it displays a strong longitudinal gradient, in which the environmental characteristics, including fish richness and composition (Okada et al. 2005), agree well with the riverine, transitional, and lacustrine zones proposed by Thornton et al. (1990; Fig. 1). Since 1983, more than 100 fish species have been recorded in the Itaipu Reservoir, mostly from complex and productive habitats in the littoral zone (Agostinho et al. 1999). The dominant species in experimental fisheries are two siluriforms (Hypophthalmus edentatus and Aucheniperus nuchalis) and the invasive freshwater croaker, Plagioscion squamosissimus (Agostinho et al. 1999). 
TABLE 1. Mean values and range (in parentheses) of environmental variables taken bimonthly, November 2005-December 2006, at experimental sites in Itaipu Reservoir on the Brazil-Paraguay border.

\begin{tabular}{lcccc}
\hline \hline \multirow{2}{*}{$\begin{array}{c}\text { Environmental } \\
\text { variable }\end{array}$} & Pooled values & Ceramic & Reef treatment \\
\cline { 3 - 5 } \multicolumn{1}{c}{ Depth $(\mathrm{m})$} & $3.17(1.7-5.4)$ & $2.58(1.9-3.6)$ & $2.77(1.7-4.2)$ & PVC \\
Transparency $(\mathrm{m})$ & $2.16(0.6-3.4)$ & $2.08(0.7-3.2)$ & $2.09(0.6-3.3)$ & $3.76(2.0-5.4)$ \\
Temperature $\left({ }^{\circ} \mathrm{C}\right)$ & $25.67(21.3-29.8)$ & $25.76(21.6-29.8)$ & $25.33(21.5-29.6)$ & $25.63(0.8-3.4)$ \\
Oxygen $(\mathrm{mg} / \mathrm{L})$ & $7.85(6.2-11.6)$ & $7.79(6.4-8.8)$ & $7.93(6.7-9.2)$ & $7.92(6.3-11.6)$ \\
Oxygen $(\%$ saturation) & $95.89(79.6-149.0)$ & $95.28(83.0-111.8)$ & $96.43(88.6-109.1)$ & $96.80(81.9-149.0)$ \\
pH & $7.35(6.4-8.3)$ & $7.34(6.6-7.9)$ & $7.39(6.6-8.0)$ & $7.32(6.6-7.8)$ \\
Conductivity $(\mu \mathrm{S} / \mathrm{cm})$ & $54.42(48.7-57.8)$ & $54.34(48.7-57.2)$ & $54.27(48.7-57.0)$ & $54.42(48.7-57.5)$ \\
\hline
\end{tabular}

\section{Experimental design and visual censuses}

Three materials were experimentally tested as artificial reefs: ceramic, concrete, and polyvinylchloride (PVC). Each artificial reef was constructed by piling $1.0 \mathrm{~m}$ long $\times 0.3 \mathrm{~m}$ diameter pipes in a pyramidal frame (10 pipes in a $4: 3: 2: 1$ base-to-top arrangement), that yielded $0.72 \mathrm{~m}^{3}$ of total volume (Fig. 1). Once controlled for dimensions and complexity, a total of nine experimental reefs (three replicates per treatment) were built to assess fish colonization.

A protected area located near the dam and within the lacustrine zone of the reservoir was selected for deploying the reefs (Fig. 1). The sites in which artificial reefs were put in place were totally depleted of natural vegetation and the substrate was composed mainly of clay and sand. Environmental characteristics of these sites are shown in Table 1, supporting that the variation among sites was negligible compared to seasonal changes.

Artificial reefs were deployed in the reservoir between 11 and 20 October 2005 by scuba divers. Ceramic and concrete pipes were piled directly onto the substrate of the reservoir until they conformed to a pyramidal shape. The PVC pipes were arranged previously with metallic clips in the $4: 3: 2: 1$ frame. In addition, three naturally unstructured sites located in the same area were also assigned as experimental controls (Fig. 1). A minimum distance of $30 \mathrm{~m}$ was set between sites to minimize the risk of fish interaction and of environmental interference among treatments. Each treatment was randomly assigned to each location and received a numbered floater attached to a concrete ballast to facilitate location.

All fish associated with treatments were identified and counted by underwater censuses. Visual censuses began in November 2005 and extended monthly to December 2006 (no data were collected in December 2005). Two scuba divers, supported by a boat with an air compressor and cables, inspected the sites between 9:30 and $16: 30$ to optimize visibility and fish identification. The order in which sites were surveyed on each sampling occasion was determined at random. Fish survey methods followed Santos et al. (2008): all fish up to $1 \mathrm{~m}$ from the structures were considered to be associated with artificial reefs, visually identified and counted, and recorded separately by each diver on an underwater writing tablet. The total length (TL) of fish was estimated visually, comparing fish size with adjacent objects of known size. Except for Cichla sp., all fish were identified to species level, and the two divers' counts were averaged (for each experimental unit by month and species) for analysis. Fish mass was estimated for each individual from published length-body mass equations (Benedito-Cecílio et al. 1997b).

\section{Data analyses}

Fish richness, abundance, biomass ( $\mathrm{g}$ ), and size (mm TL) were compared with treatment and time with generalized estimating equations (GEEs), which are an extension of generalized linear models to accommodate repeated-measures designs (Diggle et al. 2002). Generalized estimating equations were computed with the statistical package SPSS 15 (SPSS 2006). The effects of treatment and time on species composition were assessed with canonical correspondence analysis (CCA). This technique constrains the ordination of species composition to be a linear function of the environmental variables, thus using the environmental and fish composition matrices simultaneously in a single analysis (Lepš and Šmilauer 2003). Canonical correspondence analysis was performed with CANOCO 4.5 (Lepš and Šmilauer 2003), downweighting rare species and testing the significance of environmental variables with Monte Carlo permutation tests (499 permutations).

Generalized additive models (GAMs), as available in the CANOCO 4.5, were also fitted to appraise the influence of temporal colonization of artificial reefs on fish size, richness, abundance, biomass, and nine life history traits (from Lowe-McConnell 1987, Agostinho et al. 2003, Suzuki et al. 2004): spawning mode (multiple/total), spawning duration (in months), oocyte size $(\mathrm{mm})$, total fecundity (number of vitellogenic oocytes), size at first maturity (mm of standard length), gonadosomatic index (GSI), migratory behavior (sedentary species, short-distance [up to $\sim 30 \mathrm{~km}$ ] migrators, and long-distance $[>100 \mathrm{~km}]$ migrators), territorial behavior (yes/no), and parental care (as in Winemiller and Rose 1992). Generalized additive models are an extension of generalized linear models that do not assume a particular functional relationship between the response variable and the predictor (time in our case) 


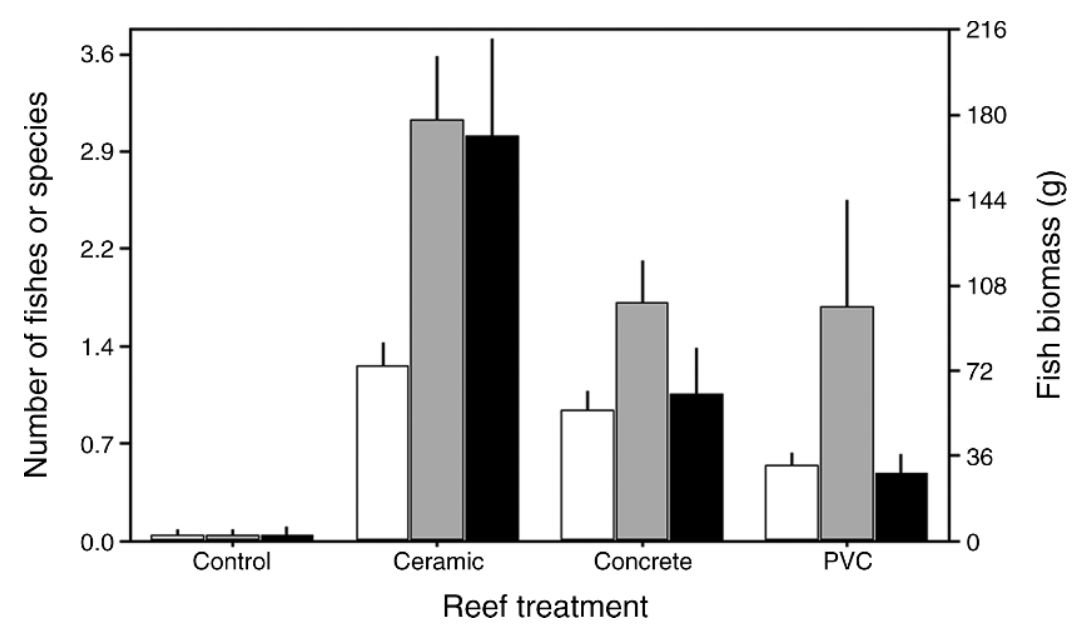

FIG. 2. Mean fish richness (no. species, open bars), abundance (no. fishes, gray bars), and biomass (black bars) recorded at the experimental reefs. Vertical lines indicate the standard error.

(Lepš and Šmilauer 2003). The model complexity of GAMs was chosen by the stepwise selection procedure using the Akaike information criterion (AIC), as available in CANOCO 4.5. AIC considers not only the goodness of fit but also parsimony, penalizing more complex models (Burnham and Anderson 1998). The data of life history traits were weighted by species occurrence (i.e., the number of reef replicates in which a species was present in a given survey) to summarize the temporal changes in functional attributes of the fish assemblages. Total fecundity and size at first maturity data were $\log _{10}$-transformed for the analyses.

Species gain, loss, and turnover rates were calculated for consecutive censuses following Anderson (2007) and then compared among treatments and time with GEEs. Rates were calculated including species that temporarily abandoned the reefs, assuming that the reappearance of a previously present species that had disappeared is related to a biologically meaningful event rather than to an artifact of sampling or population stochasticity (Anderson 2007). Generalized additive models were also fitted to evaluate the relationship of species gain, loss, and turnover with time for each reef treatment.

Our experimental reefs were separated from each other by a distance of at least $30 \mathrm{~m}$. Previous experiments with freshwater reefs have used similar distances between replicates, ranging from 3 to $100 \mathrm{~m}$ $($ median $=40 \mathrm{~m})($ Wilbur 1978, Walters et al. 1991, Hayse and Wissing 1996, Rold et al. 1996, Samdström and Karas 2002, Wills et al. 2004, Freitas et al. 2005, Santos et al. 2008). We are confident that our results are not severely affected by confusion with spatial variation or spatial dependence because: (1) the three material types were spatially interspersed (Fig. 1), i.e., adjacent reefs corresponded to different treatments, to avoid confusion of treatment effects with spatial variation (Hurlbert 1984); and (2) the sampling method used (visual censuses) is quite selective toward seden- tary fish species closely associated with submersed habitats (Bohnsack et al. 1991). In addition, to verify that the results were not affected by spatial dependence, we also used the method of principal coordinates of neighbor matrices (PCNM) (Borcard et al. 2004) in the analyses of fish richness, abundance, and biomass. PCNM obtains spatial predictors of the response variables by a principal coordinate analysis of a truncated matrix of geographic distances among the sampling sites; these predictors can then be included in further analyses (GEEs in our case) to account for spatial autocorrelation.

\section{Results}

\section{Community metrics}

Fish richness (GEE: $F_{3,156}=63.6, P<0.01$ ), abundance $\left(F_{3,156}=89.5, P<0.01\right)$, and biomass $\left(F_{3,156}=179.2, P<0.01\right)$ varied significantly among treatments, and were much higher in the artificial reefs than in the control sites, where only two individuals (one C. niederleinii and one $H$. strigaticeps) were recorded (GEE contrasts: $P<0.01$ for all; Fig. 2). Similar conclusions were observed for fish richness (GEE: $F_{3,156}$ $=37.3, P<0.01)$, abundance $\left(F_{3,156}=11.1, P=0.01\right)$, or biomass $\left(F_{3,156}=19.7, P<0.01\right)$ after accounting for spatial autocorrelation through PCNM. Fish richness was generally highest in ceramic reefs (mean $=1.31$ species), intermediate in concrete reefs, and lowest in PVC reefs (0.56 species) (GEE excluding control sites: $F_{2,117}=15.1, P<0.01$; Fig. 2). A similar trend was observed for biomass $\left(F_{2,117}=12.0, P<0.01\right)$, with ceramic treatments yielding $171.5 \mathrm{~g}$ on average, compared to only 62.5 and $28.9 \mathrm{~g}$ for concrete and PVC treatments, respectively. Abundance also differed significantly with reef material $\left(F_{2,117}=8.2, P=0.02\right)$ but differences occurred mainly between ceramic (3.0 individuals) and the other two treatments $(<1.8$ individuals; Fig. 2). Again, the same conclusions were 
observed for fish richness (GEE: $F_{2,117}=26.5, P<0.01$ ), abundance $\left(F_{2,117}=7.7, P=0.02\right)$, or biomass $\left(F_{2,117}=\right.$ $16.2, P<0.01)$ after accounting for spatial autocorrelation, indicating that the treatment differences were not due to spatial variation.

Changes of these community metrics through time were less clear, although they were significant for abundance (GEE: $F_{1,117}=30.3, P<0.01$ ) and biomass $\left(F_{1,117}=28.8, P<0.01\right)$ but not for richness $\left(F_{1,117}=\right.$ $2.0, P=0.16)$. No GAM was selected by AIC for PVC reefs, and significant models were recorded only for biomass in both ceramic $\left(F_{1,11}=9.6, P=0.01\right)$ and concrete $\left(F_{1,11}=14.4, P<0.01\right)$ treatments, with a trend of exponential increase with time (Fig. 3). The response curves for concrete reefs suggested a decelerating increase of richness with time (linear $F_{1,11}=2.2, P=$ 0.17 ) and a sharp increment of abundance (nonlinear $F_{1,11}=3.0, P=0.12$ ) in the last censuses. Conversely, response curves for ceramic reefs indicated a stabilization of richness (nonlinear $F_{1,11}=4.0, P=0.07$ ) and a unimodal response of abundance (nonlinear $F_{1,11}=4.4$, $P=0.06$ ) with time (Fig. 3).

\section{Fish assemblage variation with material type and time}

In total, 261 individuals of 13 fish species were recorded in the artificial reefs (Table 2). The most diverse group was the Siluriformes (53.8\%, 7 species), which alone accounted for $23.6 \%$ of total abundance, whereas the Perciformes, represented solely by three cichlid species, accounted for $74.1 \%$ of total abundance. Crenicichla niederleinii was the most abundant species, followed by Hypostomus strigaticeps, Pimelodella gracilis, Megalancistrus parananus, and Satanoperca pappaterra, which together accounted for $95.4 \%$ of total abundance (Table 2).

The relationship of species composition with artificial reef type and time was summarized by the two first CCA axes (Monte Carlo test, $P=0.03$ ), which respectively explained $82.6 \%$ (eigenvalue $=0.26$ ) and $11.4 \%$ (eigenvalue $=0.04)$ of the variation (total inertia $=6.1)$. The CCA biplot showed that ceramic and concrete reefs exhibited similar fish assemblages, typically with $P$. gracilis, S. pappaterra, and E. virescens, whereas some species, namely $R$. paranensis and $H$. ancistroides, occurred exclusively in PVC reefs (Fig. 4). The CCA also showed clear temporal effects on fish colonization: the characid $R$. paranensis was the first species to colonize the reefs, being subsequently replaced by an assortment of cichlids (C. niederleinii, $S$. pappaterra, and juvenile Cichla sp.), Doradidae (juvenile P. granulosus), and small Heptapteridae ( $P$. gracilis) species. The Gymnotiformes E. virescens and S. macrurus appeared afterward, while the Loricaridae species were the last fishes to colonize the reefs.

The size of the fishes associated with artificial reefs ranged from $30 \mathrm{~mm}$ (S. pappaterra) to $350 \mathrm{~mm}$ ( $M$. parananus) of TL (Table 2) but most fish were 50-150 $\mathrm{mm}$ long (Fig. 5). The three treatments did not differ

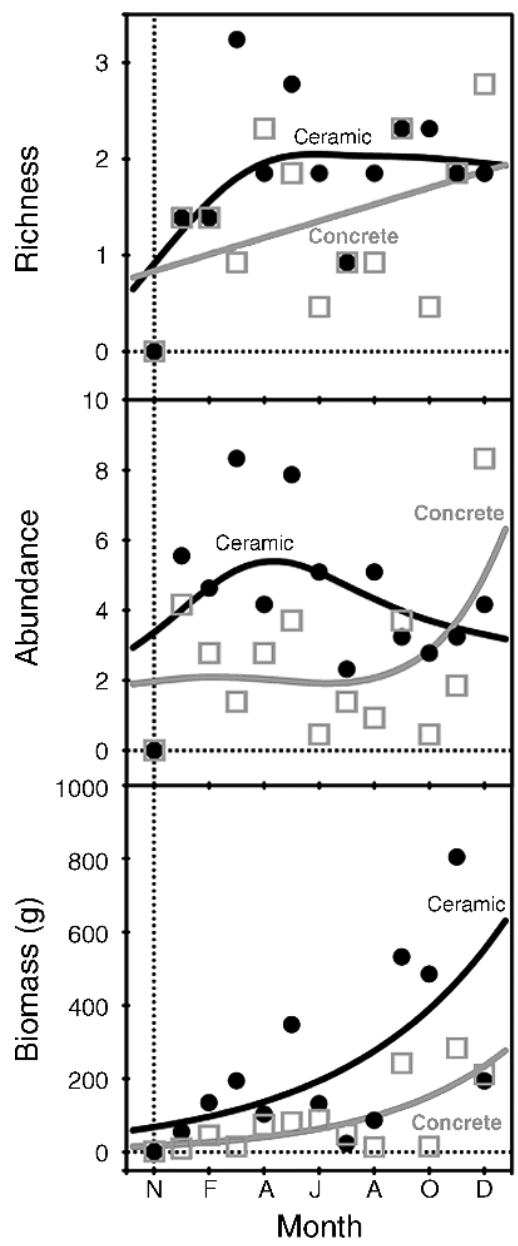

FIG. 3. Response of fish richness, abundance, and biomass with time in ceramic (solid circles, black line) and concrete (open squares, gray line) reefs. Lines are the generalized additive models selected by the Akaike information criterion.

significantly in overall fish size attained (GEE: $F_{2,117}=$ $0.7, P=0.71$ ) but on its temporal dynamics (Fig. 5). A positive linear trend of fish size was recorded only for ceramic treatments (AIC; linear $F_{1,121}=5.7, P=0.02$ ). A nonlinear response was found for concrete treatments (AIC; nonlinear $F_{1,66}=22.5, P<0.01$ ), with size initially increasing with time but then becoming highly variable after October. A similar but more unimodal relationship was found for PVC treatments (AIC; nonlinear $F_{1,65}=$ 64.0, $P<0.01)$.

Seven of the nine life history traits of the fish species (Table 3) displayed variation with time, according to the AIC-selected GAM models (Fig. 6). AIC revealed a negative linear trend for spawning mode $\left(F_{1,109}=25.5\right.$, $P<0.01)$ and parental care $\left(F_{1,109}=2.7, P=0.10\right)$, with species with low parental care and total spawners being more common in late successional stages (Fig. 6). Oocyte size and length at first maturity were positively related to time $\left(F_{1,109}=18.8\right.$ and 11.0, respectively; $P<$ 0.01 for both). AIC also suggested a nonlinear 
TABLE 2. Fish species recorded through scuba diving surveys in the experimental reefs at Itaipu Reservoir, November 2005-December 2006.

\begin{tabular}{|c|c|c|}
\hline Fish species & $\begin{array}{c}\text { Total } \\
\text { abundance }\end{array}$ & $\begin{array}{l}\text { Total length } \\
\text { range }(\mathrm{mm})\end{array}$ \\
\hline \multicolumn{3}{|l|}{ Characidae } \\
\hline Roeboides paranensis Pignalberi, 1975 & 3 & 100 \\
\hline \multicolumn{3}{|l|}{ Sternopygidae } \\
\hline Eigenmannia virescens (Valenciennes, 1842) & 2 & 180 \\
\hline Sternopygus macrurus (Bloch \& Schneider, 1801) & 1 & 150 \\
\hline \multicolumn{3}{|l|}{ Heptapteridae } \\
\hline Pimelodella gracilis (Valenciennes, 1836) & 13 & $120-180$ \\
\hline \multicolumn{3}{|l|}{ Doradidae } \\
\hline Pterodoras granulosus (Valenciennes, 1821) & 1 & 200 \\
\hline \multicolumn{3}{|l|}{ Loricariidae } \\
\hline Hypostomus ancistroides (Ihering, 1911) & 1 & 180 \\
\hline Hypostomus strigaticeps (Regan, 1908) & 31 & $50-250$ \\
\hline Loricariichthys rostratus Reis \& Pereira, 2000 & 1 & 120 \\
\hline Megalancistrus parananus (Peters, 1881) & 12 & $170-350$ \\
\hline Rhinelepis aspera Spix \& Agassiz, 1829 & 3 & $180-200$ \\
\hline \multicolumn{3}{|l|}{ Cichlidae } \\
\hline Cichla sp. & 1 & 120 \\
\hline Crenicichla niederleinii (Holmberg, 1891) & 182 & $45-300$ \\
\hline Satanoperca pappaterra (Heckel, 1840) & 10 & $30-150$ \\
\hline Total & 261 & \\
\hline
\end{tabular}

Note: Total abundance and size range for each species are shown.

relationship with time for the GSI, total fecundity $\left(F_{1,109}=2.2, P=0.14\right.$ for both), and spawning duration $\left(F_{1,109}=3.8, P=0.05\right)$, which together with spawning mode and length of first maturity, evidenced a succession from opportunistic species to a more periodic strategy (Winemiller and Rose 1992). No relationship of migratory and territorial behaviors with time was suggested by AIC.
Species gain, loss, and turnover rates also varied significantly among treatments (GEEs: $F_{2,117}=7.5, P=$ $0.02 ; F_{2,117}=5.9, P=0.05 ; F_{2,117}=21.6, P<0.01$, respectively) but mostly with time $\left(F_{2,117} \geq 77.5, P<\right.$ 0.01 for all), with a strong treatment $\times$ time interaction $\left(F_{2,117} \geq 31.5, P<0.01\right.$ for the three variables). Ceramic reefs had significantly lower rates of species gain, loss, and turnover than concrete and PVC reefs (GEE

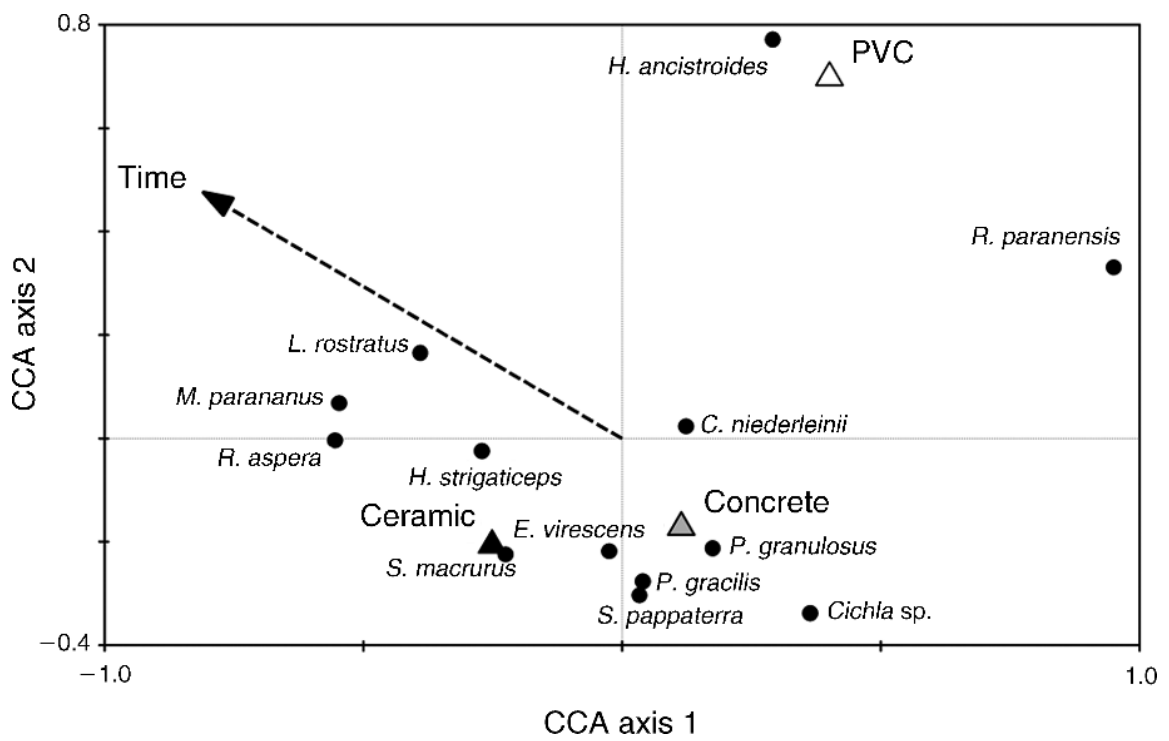

FIG. 4. Canonical correspondence analysis of fish composition (abundance) with reef treatment (ceramic, solid triangle; concrete, gray triangle; PVC, open triangle) and time. The species-environment correlations for the two axes were 0.62 and 0.26 , respectively. 


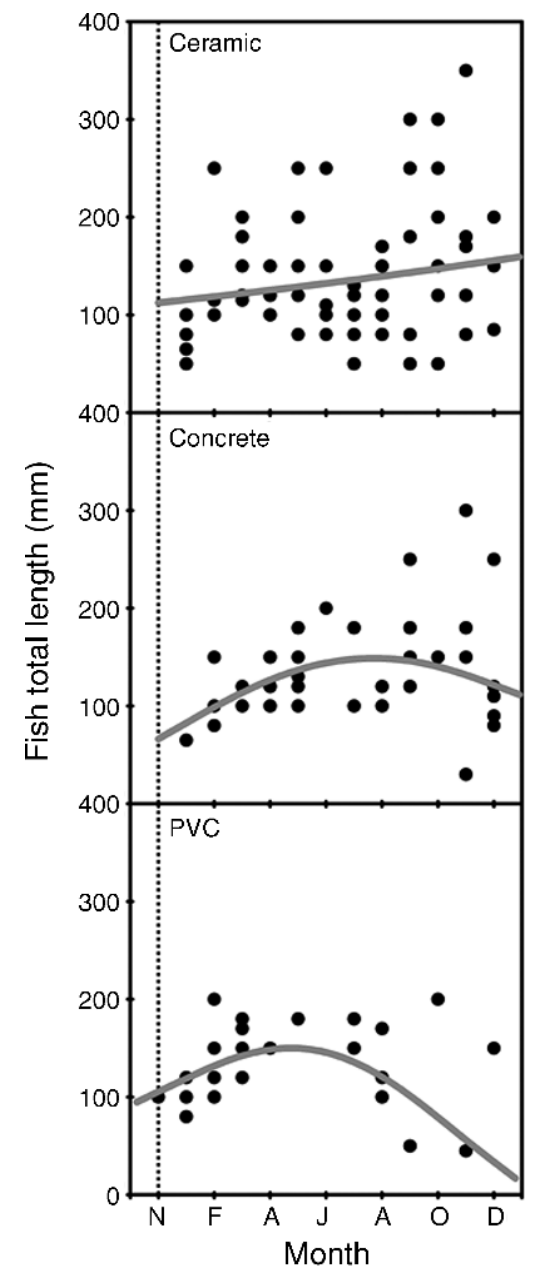

FIG. 5. Relationship of fish size with time at the ceramic, concrete, and PVC treatments. Lines are the generalized additive models selected by the Akaike information criterion. contrasts: $P<0.01)$. The temporal variation of these rates varied with material type (Fig. 7). As expected, loss rates increased and gain and turnover rates decreased with time, and the relationships were generally nonlinear and non-monotonic.

\section{DisCUSSION}

\section{Species composition and reef material}

Although the cichlid $C$. niederleinii was the prevalent species in the artificial structures throughout the year, we observed 13 of the 55 species that have been recorded in the lacustrine zone of Itaipu Reservoir (BeneditoCecílio et al. 1997a). Three siluriform species $(H$. strigaticeps, $M$. parananus, and $P$. gracilis) also consistently used the artificial reefs, amounting for $21.6 \%$ of total abundance and individually outnumbering $S$. pappaterra, the second most abundant cichlid in the reefs. In temperate reservoirs, other siluriforms (Ictalurus spp. and Ameiurus spp.) often use diverse types of artificial structures (including brush piles, artificial vegetation, and pipe reefs) but except for a lake in Florida (Wilbur 1978), they never accounted for $>2 \%$ of total abundance (Walters et al. 1991, Rold et al. 1996, Bolding et al. 2004). Using our same methodology, Santos et al. (2008) proposed that cichlids, as centrarchids in temperate systems, could be used as target species for evaluating the effectiveness of artificial structures as fish habitat in Neotropical ecosystems. The present results suggest that in addition to cichlids, siluriforms could also be used for evaluating fish colonization of Neotropical artificial reefs (Fig. 8a) and that the taxa prevailing in the reefs can be very variable, even within regions of similar faunistic composition.

Ceramic reefs were more promptly colonized by fish than concrete reefs, whereas PVC treatments had the lowest richness, abundance, and biomass. Community change rates indicated that although ceramic reefs were more promptly colonized, concrete reefs benefited from

TABLE 3. Life history traits of the species recorded in the experimental reefs, compiled from the literature.

\begin{tabular}{|c|c|c|c|c|c|c|c|c|c|}
\hline Fish species & $\begin{array}{l}\text { Spawning } \\
\text { mode }\end{array}$ & $\begin{array}{c}\text { Oocyte } \\
\text { size }(\mathrm{mm})\end{array}$ & $\begin{array}{c}\text { Total } \\
\text { fecundity }\end{array}$ & $\begin{array}{l}\text { Size at } \\
\text { first maturity } \\
(\mathrm{mm})\end{array}$ & GSI & $\begin{array}{c}\text { Parental } \\
\text { care }\end{array}$ & $\begin{array}{l}\text { Spawning } \\
\text { duration } \\
\text { (months) }\end{array}$ & $\begin{array}{c}\text { Migratory } \\
\text { behavior }\end{array}$ & $\begin{array}{c}\text { Territorial } \\
\text { behavior }\end{array}$ \\
\hline R. paranensis & multiple & 0.92 & 280 & 43 & 16.45 & 0 & 6 & short & no \\
\hline E. virescens & multiple & 1.95 & 1332 & 125 & 10.81 & 2 & 2 & no & yes \\
\hline S. macrurus & multiple & 2.30 & 1639 & 280 & 9.42 & 2 & 3 & no & yes \\
\hline P. gracilis & multiple & 0.64 & 10955 & 78 & 9.88 & 1 & 5 & short & no \\
\hline P. granulosus & multiple & 1.06 & 296000 & 337 & 7.81 & 0 & 4 & long & no \\
\hline H. ancistroides & total & 5.00 & 2802 & 67 & 23.58 & 4 & 11 & no & yes \\
\hline H. strigaticeps & total & 5.00 & 2802 & 67 & 23.58 & 4 & 11 & no & yes \\
\hline L. rostratus & multiple & 2.81 & 619 & 132 & 14.75 & 4 & 6 & no & no \\
\hline M. parananus & total & 4.79 & 13022 & 175 & 14.06 & 4 & 3 & no & yes \\
\hline R. aspera & total & 1.34 & 181200 & 200 & 16.46 & 0 & 4 & long & no \\
\hline Cichla sp. & multiple & 2.69 & 33786 & 200 & 6.00 & 6 & 5 & no & yes \\
\hline C. niederleinii & multiple & 2.34 & 1786 & 73 & 7.52 & 6 & 3 & no & yes \\
\hline S. pappaterra & multiple & 2.03 & 1646 & 86 & 3.70 & 6 & 4 & no & yes \\
\hline
\end{tabular}

Notes: GSI is the gonadosomatic index. See Methods for the reference sources and the values of parental care. 

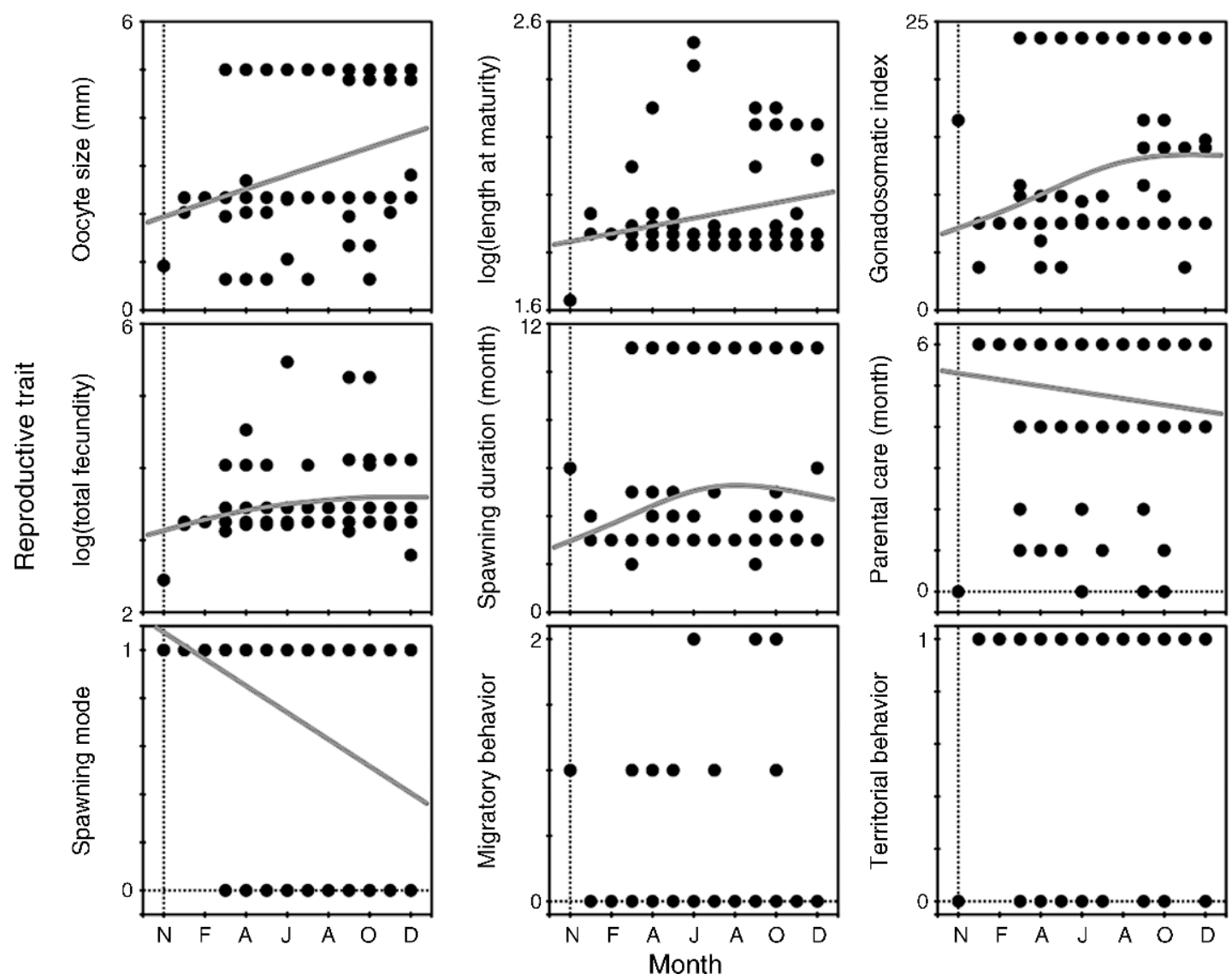

FIG. 6. Relationship of spawning mode ( 0 , multiple spawner [two or more bouts of reproduction per spawning season]; 1 , total spawner [only one bout of reproduction per spawning season]), spawning duration, oocyte size, total fecundity ( $\log _{10}[$ [number of vitellogenic oocytes]), standard length at maturity ( $\log _{10}[$ length in millimeters $]$ ), gonadosomatic index (investment in reproduction: percentage of gonad mass to total mass), migratory behavior ( 0 , sedentary species; 1 , short-distance [up to $\sim 30 \mathrm{~km}$ ] migrators; 2 , long-distance [ $>100 \mathrm{~km}$ ] migrators), territorial behavior $(0$, no; 1 , yes), and parental care (ranging from 0 [none] to 8 [high], as in Winemiller and Rose [1992]) with time (months). Dots represent the values of reproductive traits for each species recorded at reef treatments in a given month. Lines are the generalized additive models selected by the Akaike information criterion.

a secondary increase in species gain rates, following the initial decrease which is general of most successions (Anderson 2007). We believe that these differences are not due to confounding environmental variables or the physical complexity and size of the reefs, which have been shown to affect the availability of predation refuges, food, or spawning substrata (Walters et al. 1991, Rold et al. 1996, Bolding et al. 2004, Wills et al. 2004), because we carefully matched the dimensions and complexity of the reefs, and we placed the reefs in an environmentally homogeneous area, with no detectable differences in physicochemical features among sites. Although further data are needed to understand the mechanisms generating these differences among materials, ceramic and concrete were more promptly and intensively colonized by periphyton than the PVC treatments (L. N. Santos, personal observation), which also had a different species composition. The importance of periphyton and macroinvertebrate communities on the use of artificial structures by fish has been previously noted (Pardue 1973, Moring et al. 1986, Santos et al. 2008).

\section{Fish colonization and successional changes}

The theory of ecological succession has been mostly developed in terrestrial ecosystems (Anderson 2007) but has also been applied to fish colonization of marine artificial reefs, which generally achieve a relative stable assemblage structure within one to five years (Bohnsack et al. 1991). Our results confirm that colonization of artificial reefs matches many of the regularities often observed in ecological successions (Connell and Slatyer 1977, Anderson 2007), including decelerating increases in species richness, abundance, mean individual size, and species loss rates, and decelerating decreases of species gain and turnover rates. Most of these successional patterns were, however, clearly mediated by material type, and thus ceramic reefs achieved a higher richness and biomass more quickly than concrete treatments, whereas PVC reefs were poorly colonized. 
Species composition (CCA results) also varied with time and reef material. Interestingly, this temporal variation in species composition also implied variation in life history traits. The response curves of life history traits with time showed that the first species to populate the reefs corresponded to those of a more opportunistic strategy (i.e., small rapidly maturing, short lived fishes), whereas those colonizing the reefs later were more of the equilibrium strategy (i.e., fishes of intermediate size that often exhibit parental care and produce fewer but larger offspring) in the WinemillerRose triangular model (Winemiller and Rose 1992, Vila-Gispert et al. 2002, Suzuki et al. 2004; see Fig. 8b). Spawning mode, oocyte diameter, length-at-maturity, and spawning duration were the traits that changed more clearly with colonization of the experimental reefs. As expected, no model was selected by AIC for migratory and territorial behaviors because the abundance of true rheophilic species (e.g., long-distance migrators and non-territorial fishes) is presently very low in the lacustrine zone of the reservoir (Okada et al. 2005). In artificial reefs at a Floridian lake, Wilbur (1978) showed that centrarchids (Micropterus salmoides, Lepomis macrochirus, Lepomis microlophus, Lepomis gulosus, and Pomoxis nigromaculatus) prevailed in number at brush and pipe reefs within 12-18 months after reef deployment, being subsequently outnumbered by catfishes (Ameiurus catus and Ameiurus nebulosus). Catfishes correspond to a more equilibrium strategy than centrarchids (Winemiller and Rose 1992), so Wilbur's (1978) results also match our findings of a replacement of more opportunistic with more equilibrium species with reef colonization (Fig. $8 b)$. Further studies are necessary to confirm whether the Winemiller-Rose model is of use in reef experiments and hence functional traits might be used in addition to species composition.

Anderson (2007) has recently classified successional series in a triangular continuum, depending on the importance of competition, dispersal, or abiotic limitations. We observed a nonlinear decrease in species gain rates and a rather non-monotonic relationship of turnover rates with time, which according to Anderson (2007) corresponds to an ecosystem not limited by dispersal and confirms our expectations given the properties of the system studied (high species richness and large ecosystem size). Although Anderson (2007) emphasized the role of competition, she also acknowledged that other trophic interactions, such as predation, can also play an important role. We believe that, in addition to competition, predation also played a role in reef colonization at Itaipu Reservoir because several large (250-550 mm TL) individuals of the freshwater croaker Plagioscion squamosissimus, an invasive piscivorous fish of nocturnal and benthopelagic habits, were caught by experimental gill nets deployed near the reefs (L. N. Santos, unpublished data).

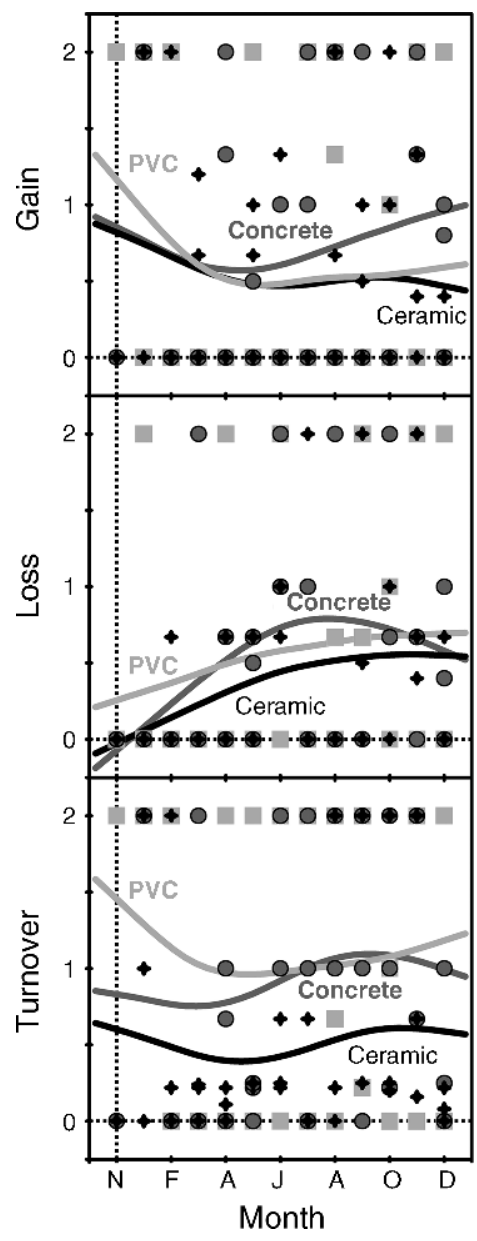

FIG. 7. Response of fish species gain, loss, and turnover rates with time in ceramic $(+$ sign; black line), concrete (solid circle; dark gray line), and PVC (gray square; light gray line) reefs. Lines are the generalized additive models selected by the Akaike information criterion.

\section{Management implications}

The attraction vs. production debate, although extensively discussed for marine reefs (Lindberg 1997, Brickhill et al. 2005), is a controversial issue that has been assessed just superficially for freshwater reefs (Bassett 1994, Santos et al. 2008). We cannot help to solve this debate on whether reefs actually increase fish production or merely redistribute fish biomass without augmenting production, but the two alternatives might take place with the development of artificial reef programs in Itaipu Reservoir (Fig. 8c). If ceramic or concrete pipe reefs are deployed within non-fishing reserves, in a fashion that a great amount of reef units (i.e., pyramidal modules) would be placed in an aggregated spatial configuration and covering extensive areas, they will have the potential to promote a true increase on the populations of lithophilic species, namely Hypostomus spp., M. parananus, and $R$. aspera. Such species have been traditionally exploited by local 

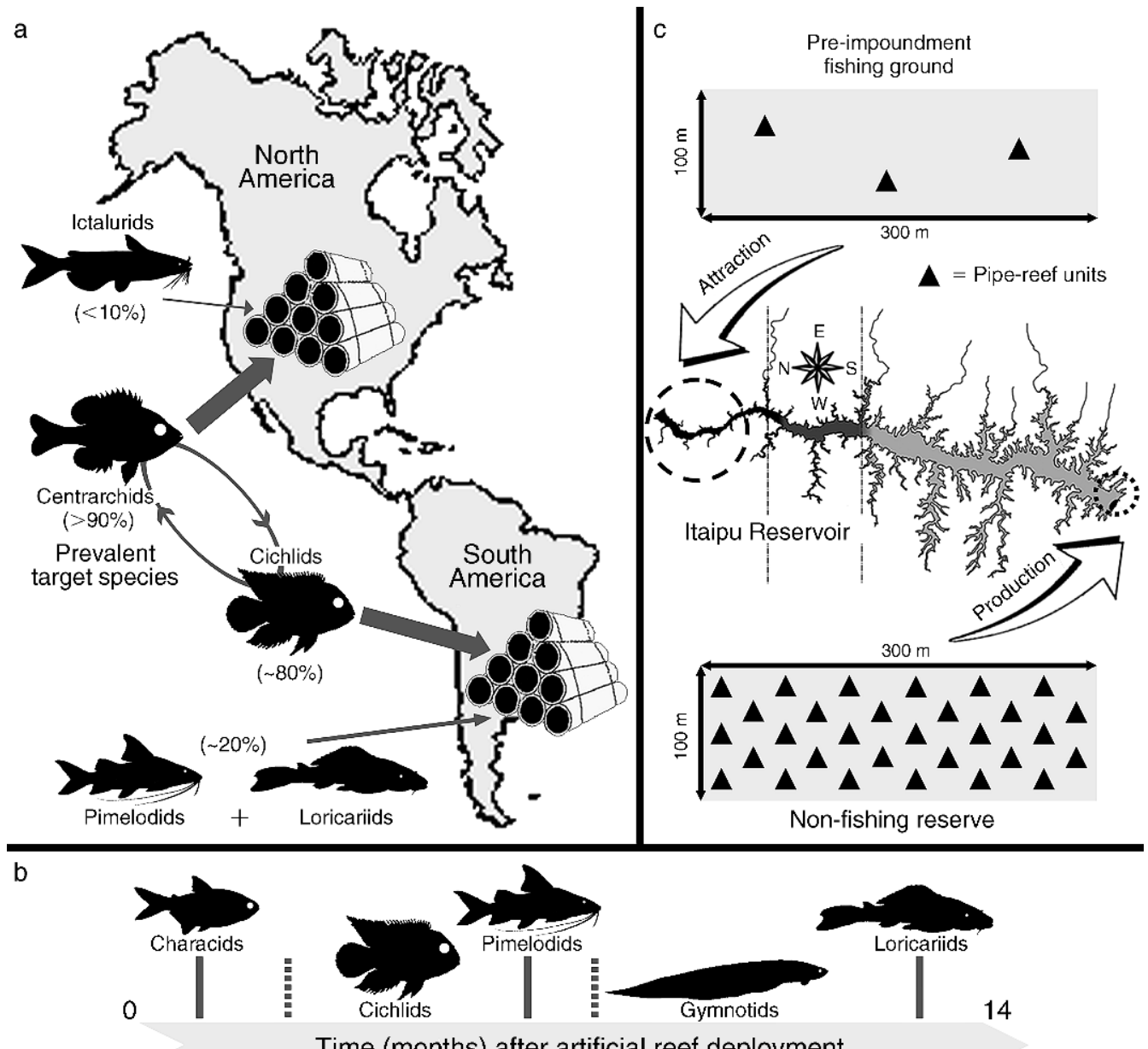

Time (months) after artificial reef deployment

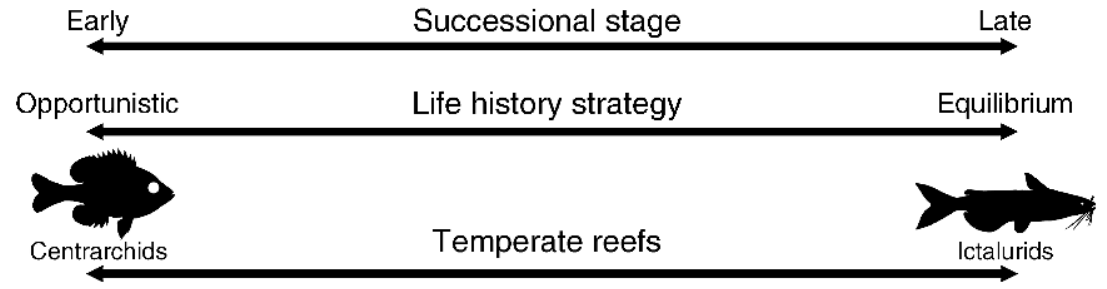

FIG. 8. Conceptual models of (a) the use of freshwater reefs in North and South America by the prevalent fish species (the width of arrows denotes the contribution per fish group); (b) the temporal sequence of fish species substitution with ecological succession in artificial reefs of the Neotropics (above) and temperate regions (below), showing the general trends expected for life history strategy and species replacement; (c) the differential management application of artificial reefs in the Itaipu Reservoir, according to attraction (above) or production (below) interests.

fisheries, but their stocks and capture rates were adversely affected by the impoundment, which increased the depth and silted the natural hard substrates (rocky shores) where these species previously occurred (Okada et al. 2005). Otherwise, if small-sized pipe reefs are deployed in a more scattered spatial configuration and on shallow littoral areas allowed for fishing, such structures will be prone to function as fish attractor devices (FADs), enhancing the capture success of those lithophilic species that would be more concentrated rather in hard substrates than in the adjacent soft- bottom areas. Thus, we hypothesize that the extent of attraction and production effects in Itaipu Reservoir would be largely dependent on fishery management protocols.

In conclusion, our results show a clear variation in fish colonization with reef material type and the potential of artificial reefs to enhance our understanding of ecological succession in freshwater fish assemblages. Our results also highlight the importance of considering reef material type and successional patterns of fish colonization in order to improve the positive effects 
(e.g., habitat enhancement for native species) and to minimize the risks of detrimental impacts (e.g., overfishing) of large-scale artificial reef programs.

\section{ACKNOWLEDGMENTS}

We thank V. A. Capatti, F. A. Teixeira, J. R. Gonçalves, and V. R. Casaré for assistance in field work, S. A. Heil, D. R. Fernandez, and H. M. Fontes, Jr., for logistic support, and anonymous reviewers for helpful comments on the manuscript. This research is part of the first author's Ph.D. thesis and was funded by Conselho Nacional de Desenvolvimento Científico e Tecnológico, Brazil (graduate grant to L. N. Santos, code 210199/2006-7; Edital Universal, code 478541/2004-0), Programme Alßan of the European Union (Programme of High Level Scholarships for Latin America, grant to L. N. Santos), and the Government of Catalonia (Catalan Government Distinction Award for University Research 2004 to E. García-Berthou).

\section{Literature Cited}

Agostinho, A. A., L. C. Gomes, H. I. Suzuki, and H. F. Júlio, Jr. 2003. Migratory fishes of the Upper Parana River Basin, Brazil. Pages 19-99 in J. Carolsfeld, B. Harvey, C. Ross, and A. Baer, editors. Migratory fishes of South America: biology, fisheries and conservation status. World Fisheries Trust, Victoria, Canada.

Agostinho, A. A., F. M. Pelicice, A. C. Petry, L. C. Gomes, and H. F. Julio, Jr. 2007. Fish diversity in the upper Paraná River basin: habitat, fisheries, management and conservation. Aquatic Ecosystem Health and Management 10:174-186.

Agostinho, A. A., S. M. Thomaz, and L. C. Gomes. 2005. Conservation of the biodiversity of Brazil's inland waters. Conservation Biology 19:646-652.

Agostinho, A. A., S. M. Thomaz, L. E. Miranda, L. M. Bini, L. C. Gomes, and H. I. Suzuki. 1999. Patterns of colonization in neotropical reservoirs, and prognoses on aging. Pages 227265 in J. G. Tundisi and M. Straskraba, editors. Theoretical reservoir ecology and its applications. International Institute of Ecology/Backhuys Publishers/Brazilian Academy of Sciences, Rio de Janeiro, Brazil.

Anderson, K. J. 2007. Temporal patterns in rates of community change during succession. American Naturalist 169:780-793.

Andrade, L. F., R. F. Brunkow, C. F. Xavier, and L. L. Domingues. 1988. Fitoplâncton e características físicoquímicas do reservatório de Itaipu-BR. Pages 205-268 in J. G. Tundisi, editor. Limnologia e Manejo de Represas. Universidade de São Paulo/Academia de Ciências do Estado de São Paulo, São Paulo, Brazil.

Bassett, C. E. 1994. Use and evaluation of fish habitat structures in lakes of the eastern United States by USDA Forest Service. Bulletin of Marine Science 55:1137-1148.

Benedito-Cecílio, E., A. A. Agostinho, H. F. Júlio Jr, and C. S. Pavanelli. 1997a. Colonização ictiofaunística do reservatório de Itaipu e áreas adjacentes. Revista Brasileira de Zoologia 14:1-14.

Benedito-Cecílio, E., A. A. Agostinho, and R. C. C. M. Velho. 1997b. Length-weight relationship of fishes caught in the Itaipu Reservoir, Paraná, Brazil. NAGA The ICLARM Quarterly 20:57-61.

Bohnsack, J. A., D. L. Johnson, and R. F. Ambrose. 1991. Ecology of artificial reef habitats and fishes. Pages 61-107 in W. Seaman, Jr. and L. M. Sprague, editors. Artificial habitats for marine and freshwater fisheries. Academic Press, San Diego, California, USA.

Bolding, B., S. Bonar, and M. Divens. 2004. Use of artificial structure to enhance angler benefits in lakes, ponds, and reservoirs: a literature review. Reviews in Fisheries Science 12:75-96.
Borcard, D., P. Legendre, C. Avois-Jacquet, and H. Tuomisto. 2004. Dissecting the spatial structure of ecological data at multiple scales. Ecology 85:1826-1832.

Brickhill, M. J., S. Y. Lee, and R. M. Connolly. 2005. Fishes associated with artificial reefs: attributing changes to attraction or production using novel approaches. Journal of Fish Biology 67:53-71.

Burnham, K. P., and D. R. Anderson. 1998. Model selection and inference. Springer-Verlag, New York, New York, USA.

Connell, J., and R. Slatyer. 1977. Mechanisms of succession in natural communities and their role in community stability and organization. American Naturalist 111:1119-1144.

Diggle, P. J., P. Heagerty, K. Y. Liang, and S. L. Zeger. 2002. The analysis of longitudinal data. Oxford University Press, Oxford, UK.

Freitas, C. E. C., M. Petrere, Jr., and M. A. P. Abuabara. 2002. Artificial reefs and their effects on fish assemblages in a Brazilian reservoir and tailrace. Ecohydrology and Hydrobiology 2:305-313.

Freitas, C. E. C., M. Petrere, Jr., and W. Barrella. 2005. Natural and artificially-induced habitat complexity and freshwater fish species composition. Fisheries Management and Ecology 12:63-67.

Hayse, J. W., and T. E. Wissing. 1996. Effects of stem density of artificial vegetation on abundance and growth of age- 0 bluegills and predation by largemouth bass. Transactions of the American Fisheries Society 125:422-433.

Hurlbert, S. H. 1984. Pseudoreplication and the design of ecological field experiments. Ecological Monographs 54:187211.

Lepš, J., and P. Šmilauer. 2003. Multivariate analysis of ecological data using CANOCO. Cambridge University Press, Cambridge, UK.

Lindberg, W. J. 1997. Can science resolve the attractionproduction issue? Fisheries 22:10-13.

Lowe-McConnell, R. H. 1987. Ecological studies in tropical fish communities. Cambridge University Press, Cambridge, UK.

Molles, M. C. 1978. Fish species on model and natural reef patches: experimental insular biogeography. Ecological Monographs 48:289-306.

Moring, J. R., P. D. Eiler, M. T. Negus, and K. E. Gibbs. 1986. Ecological importance of submerged pulpwood logs in a Maine reservoir. Transactions of the American Fisheries Society 115:335-342.

Okada, E. K., A. A. Agostinho, and L. C. Gomes. 2005. Spatial and temporal gradients in artisanal fisheries of a large Neotropical reservoir, the Itaipu Reservoir, Brazil. Canadian Journal of Fisheries and Aquatic Sciences 62:714-724.

Pardue, G. B. 1973. Production response of the bluegill sunfish, Lepomis macrochirus Rafinesque, to added attachment surface for fish-food organisms. Transactions of the American Fisheries Society 3:622-626.

Rold, R. E., T. S. McComish, and D. E. van Meter. 1996. A comparison of cedar trees and fabricated polypropylene modules of fish attractors in a strip mine impoundment. North American Journal of Fisheries Management 16:223227.

Samdström, A., and P. Karas. 2002. Tests of artificial substrata as nursery habitat for young fish. Journal of Applied Ichthyology 18:102-105.

Santos, L. N., F. G. Araújo, and D. S. Brotto. 2008. Artificial structures as tools for fish habitat rehabilitation in a neotropical reservoir. Aquatic Conservation: Marine and Freshwater Ecosystems 18:896-908.

SPSS. 2006. SPSS 15. SPSS, Chicago, Illinois, USA.

Suzuki, H. I., F. M. Pelicice, E. A. Luiz, J. D. Latini, and A. A. Agostinho. 2004. Reproductive strategies of the fish community of the Upper Paraná river floodplain. Pages 125-130 in A. A. Agostinho, L. Rodrigues, L. C. Gomes, S. M. Thomaz, and L. E. Miranda, editors. Structure and functioning of the 
Paraná River and its floodplain. EDUEM, Maringá, Paraná, Brazil.

Talbot, F. H., B. C. Russell, and G. R. V. Anderson. 1978. Coral reef fish communities: unstable, high-diversity systems? Ecological Monographs 48:425-440.

Thornton, K. W., B. L. Kimmel, and F. E. Payne. 1990. Reservoir limnology: ecological perspectives. Wiley-Interscience, New York, New York, USA.

Vila-Gispert, A., R. Moreno-Amich, and E. García-Berthou. 2002. Gradients of life-history variation: an intercontinental comparison of fishes. Reviews in Fish Biology and Fisheries 12:417-427.

Walters, D. A., W. E. Lynch, and D. L. Johnson. 1991. How depth and interstice size of artificial structures influence fish attraction. North American Journal of Fisheries Management 11:319-329.

Wilbur, R. L. 1978. Two types of fish attractors compared in Lake Tohopekaliga, Florida. Transactions of the American Fisheries Society 107:689-695.

Wills, T. C., M. T. Bremigan, and D. B. Hayes. 2004. Variable effects of habitat enhancement structures across species and habitats in Michigan reservoirs. Transactions of the American Fisheries Society 133:399-411.

Winemiller, K. O., and K. A. Rose. 1992. Patterns of lifehistory diversification in North American fishes: implications for population regulation. Canadian Journal of Fisheries and Aquatic Sciences 49:2196-2218. 